\title{
The Influence of Three Years of Tillage and Poultry Manure Application on Soil and Leaf Nutrient Status, Growth and Yield of Cocoyam
}

\author{
Aruna O. Adekiya ${ }^{1}$ and Taiwo M. Agbede ${ }^{2}$ \\ ${ }^{1}$ Department of Crop and Soil Sciences, Landmark University, P.M.B. 1001, Omu-Aran, Kwara State, Nigeria \\ ${ }^{2}$ Department of Agricultural Technology, Rufus Giwa Polytechnic, P.M.B. 1019, Owo, Ondo State, Nigeria \\ Email: agbedetaiwomichael@yahoo.com
}

\begin{abstract}
A three-year (2007 to 2009) study was conducted to evaluate the effect of twenty five tillage-manure treatments on soil and leaf nutrients composition, growth and yield of cocoyam (Xanthosoma sagittifolium). The study was a $5 \times 5$ factorial experiment with five tillage methods; manual clearing (MC), manual ridging (MR), manual mounding (MM), ploughing plus harrowing $(\mathbf{P}+\mathbf{H})$ and ploughing plus harrowing twice $(\mathrm{P}+2 \mathrm{H})$-and five levels of poultry manure $(P M)(0,2.5,5.0,7.5,10.0$ t/ha). Treatments were replicated thrice. Soil OM, N, P, K, Ca, Mg and leaf nutrients reduced with increase in tillage intensity, thus MC conserved soil nutrients the-most, and increased nutrient uptake. Soil and leaf nutrient concentration was lowest under the $\mathrm{P}+2 \mathrm{H}$ treatment. The MC, MR and MM treatments led to faster growth and higher tuber yield. As poultry manure increased from 0 to 10.0 t/ha soil $\mathrm{pH}, \mathrm{OM}$, soil and leaf N, P, K, Ca and Mg increased. The 7.5t/ha PM gave the highest leaf $\mathrm{K}, \mathrm{Ca}$ and $\mathrm{Mg}$ values. Yield and growth parameters of cocoyam increased with increase in PM level up to $7.5 \mathrm{t} / \mathrm{ha}$. Out of the 25 tillage cum manure treatments, MC+7.5t/ha PM gave the highest values of yield and growth parameters and was followed by $\mathrm{MC}+5.0 \mathrm{t} / \mathrm{ha}$ $\mathrm{PM}$ and $\mathrm{MC}+2.5 \mathrm{t} / \mathrm{ha}$ respectively.
\end{abstract}

Index Terms - tillage, poultry manure, soil and leaf nutrient concentration, cocoyam

\section{INTRODUCTION}

Cocoyam (Xanthosoma sagittifolium (L.) Schott), a member of the Araceae family, is a subsistence and emergency food source in many parts of the world, but a major staple food crop in Nigeria (a leading producer of cocoyam), South Pacific Islands and some parts of Asia [1]. The corms and cormels are eaten boiled, fried, baked and roasted. In West Africa, the boiled cocoyam is sometimes pounded to produce a paste similar to pounded yam and eaten in the same manner. The corms and cormels may be peeled, dried and ground into flour and thus stored in a semi-processed form. The young leaves and petioles are made into soup, while the corms, cormels and leaves after curing can also be used as animal feed [2]. Cocoyams are the cheapest and most handy source of carbohydrate in meals that are

Manuscript received August 31, 2015, revised October 16, 2015. recommended for aged people, diabetics, convalescents and most gastro-intestinal disorder patients and a good carbohydrate base for infant foods on account of their small-sized starch grains which are easily digested compared to yam (Dioscorea spp), cassava (Manihot spp) or sweet potato (Ipomoea batatas) [3], [1]. However, the crop has not received research attention particularly concerning its tillage and manure requirements.

Tillage and use of organic manure are important agronomic practices that sustain high crop and soil productivity. Studies on tillage requirement for cocoyam are few and gave differing results [4]. Hence there is need to study the tillage requirement and soil conditions influencing cocoyam in order to raise production level from the average yield of $5.1 \mathrm{Mt} / \mathrm{ha}$ to the potential yields of $8.0 \mathrm{Mt} / \mathrm{ha}$ and meet the demand for the corms and cormels. Also previous studies were short-termed; aside from being inconclusive. Ref. [5] studied the effect of tillage intensity on production of upland taro (cocoyam) and found no significant differences between ploughing and harrowing once or twice. Ref. [6] recommended ploughing once with the incorporation of farmyard manure, followed by harrowing, and if necessary, either mounding or ridging. In the Philippines, Pardales and Villamayor [7] also found that ploughing and harrowing once was sufficient for taro (cocoyam) production. Ref. [8] cited by Onwueme [9] reported that the yield of cocoyam (Xanthosoma spp.) is higher and corm shape is better when planted on ridges. Also, research information is quite scarce on the effect of organic wastes on soil chemical properties and performance of cocoyam. In Hawaii, taro (cocoyam) is usually grown in puddled flooded soils with high inputs of fertilizers, resulting in very high yields of up to 60t/ha [10] cited by Agbede [11]. Ref. [12] found that the application of the recommended N, P and $\mathrm{K}$ fertilizer rates of 200 and $250 \mathrm{~kg} / \mathrm{ha}$ at Nsukka (Enugu State) and Umudike (Abia State), respectively on Ultisol grown to cocoyam in the southeast of Nigeria is not sustainable due to scarcity and high cost of chemical fertilizer. Moreover, the fertilizer did not lead to expected yield levels due to leaching of nutrients. Ref. [13], in their two-year study, found that in the second year poultry manure applied up to $120 \mathrm{~kg} \mathrm{~N} / \mathrm{ha}$ increased corm plus cormel yield from 8.4 to $18.7 \mathrm{t} / \mathrm{ha}$, 
but above this rate decreased the yield of cocoyam. Also swine and cow manures increased yield up to $180 \mathrm{~kg} \mathrm{~N} / \mathrm{ha}$. Ref. [14] observed that it is possible to increase yield of crops on physically degraded soils by using organic resources such as manure for soil fertility improvement after adopting appropriate tillage practices. To this end, this paper reports a three-year study conducted at Owo in the forest-savanna transition zone of Nigeria to determine the effects of different tillage methods, poultry manure, and tillage cum poultry manure treatments on soil and leaf nutrients composition, growth and yield of cocoyam on an Alfisol in southwest Nigeria.

\section{MATERIALS AND MethodS}

\section{A. Site Description and Experimental Design}

Field experiments were conducted at Owo (latitude $7^{\circ} 13^{\prime} \mathrm{N}$, longitude $5^{\circ} 32^{\prime} \mathrm{E}$ ) in the forest-savanna zone of southwest Nigeria. The soil at Owo belongs to the broad group Alfisol classified as Oxic Tropuldalf or Luvisol [15]. The experimental site had been under bush fallow for two years after arable cropping to a variety of crops such as yam (Dioscorea rotundata Poir), maize (Zea mays L.), groundnut (Arachis hypogaea L.), cassava (Manihot esculenta Crantz), melon (Colosynthis citrullus L.), etc. The predominant weeds at the site were Siam weed (Chromolaena odorata L. King and Robinson), Water leaf (Talinum triangulare Jacq. Wild), Guinea grass (Panicum maximum Jacq. and Haemorrhage plant (Aspilia africana Pers. Adams), interspersed with shrubs. The experiments were conducted to assess the long term effect (at year three) of cropping and soil management method on soil and leaf nutrients composition, growth and yield of cocoyam.

The experiments consisted of $5 \times 5$ factorial combinations of five tillage methods: Manual Clearing (MC), Manual Ridging (MR), Manual Mounding (MM), ploughing plus harrowing $(\mathrm{P}+\mathrm{H})$, and ploughing plus harrowing twice $(\mathrm{P}+2 \mathrm{H})$ and five poultry manure levels $(0,2.5,5.0,7.5$ and $10.0 \mathrm{t} / \mathrm{ha})$. The rate of $7.5-10.0 \mathrm{t} / \mathrm{ha}$ was recommended for cocoyam production [16], [17]. The 25 treatment combinations were arranged in a randomized complete block design and replicated thrice. Each block comprised 25 plots, each of which measured $12 \mathrm{~m} \times 10 \mathrm{~m}$. Tillage was followed by initial manual clearing with cutlass. The same treatment was allotted to each plot for the three years of study.

\section{B. Crop Establishment}

Tillage was done in April each year (2007, 2008, and 2009). Cocoyam cormels weighing about $150 \mathrm{~g}$ were planted each year. A cormel was planted per hill at $1 \mathrm{~m} \times 1 \mathrm{~m}$ to give 10,000 plants per hectare. Poultry manure was applied 3 weeks after planting by ring method. Weeding was done manually at 45 and 110 days after planting. The same treatment was applied to each plot for the three years.

\section{Soil Analysis}

Prior to the commencement of the experiment in 2007, soil samples were taken from 0 to $15 \mathrm{~cm}$ depth at the experimental site using steel core tubes. Ten core samples collected at the site were used for determination of bulk density after oven drying at $100^{\circ} \mathrm{C}$ for $24 \mathrm{hr}$. Total porosity was calculated from bulk density using particle density of $2.65 \mathrm{Mg} / \mathrm{m}^{3}$. Mechanical analysis was done using hydrometer method. Surface samples collected over the site were bulked, air dried with $2 \mathrm{~mm}$ sieved for chemical analysis. Also samples collected over each plot at harvest of cocoyam in 2009 were analysed for chemical properties [18]. The Organic Matter (OM) was determined by Walkley and Black procedure using dichromate wet oxidation method, total $\mathrm{N}$ by microKjeldahl digestion method, available $\mathrm{P}$ by Bray -1 extraction followed by molybdenum colorimetry. Exchangeable $\mathrm{K}, \mathrm{Ca}$ and $\mathrm{Mg}$ were extracted with $1 \mathrm{M}$ ammonium acetate. Thereafter, $\mathrm{K}$ was determined using flame photometer, and $\mathrm{Ca}$ and $\mathrm{Mg}$ by EDTA titration method. Soil $\mathrm{pH}$ was determined in soil water medium at ratio of 1:2 using the digital electronic $\mathrm{pH}$ meter.

\section{Leaf Analysis}

In 2009, 2 to 3 weeks old cocoyam leaves were collected at 168 days after planting (DAP) when the cocoyam plant reached its peak growth [19], [20]. The leaves were collected from ten plants per plot for chemical analysis. The samples were oven-dried for $24 \mathrm{hr}$ at $70^{\circ} \mathrm{C}$ and ground. Leaf $\mathrm{N}$ was determined by micro$\mathrm{Kjeldahl}$ approach. Samples were dry ashed at $500^{\circ} \mathrm{C}$ for $6 \mathrm{hr}$ in a furnace and extracted using nitric-perchloricsulphuric acid mixture for the determination of $\mathrm{P}, \mathrm{K}, \mathrm{Ca}$ and $\mathrm{Mg}$. Leaf $\mathrm{P}$ was determined using vanadomolybdate colorimetry method. K was determined using a flame photometer, and $\mathrm{Ca}$ and $\mathrm{Mg}$ were determined by EDTA titration method [18].

\section{E. Growth and Yield Parameters}

Twenty plants were selected per plot for determination of plant height and leaf area per plant at 168 days after planting (DAP) when the cocoyam plant reached its peak growth in 2009. Plant height was measured from the ground level to the shoot apex. Leaf area was estimated using the mathematical model developed by Agueguia [21] between linear measurements of leaves. It relates leaf area (Y) to the product of length (L) and breadth (B).

$$
Y=k(L B)
$$

where the constant, $k=0.923+0.004$

The corm and cormel yields were determined by harvesting twenty cocoyam plants per plot and separated them into corms and cormels. They were washed and cleaned to remove traces of sand before weighing on a top loading balance to determine their fresh weights.

\section{F. Preparation and Analysis of Manure}

The poultry manure used each year was stacked a week under a shed to allow for mineralization, samples were analysed for nutrient composition after being airdried and crushed to pass through a $2 \mathrm{~mm}$ sieve. Analysis was done for Organic Carbon (OC), N, P, K, Ca and Mg [18]. 


\section{G. Statistical Analysis}

Data collected in 2009 were subjected to analysis of variance test and treatment means were compared using the Duncan's Multiple Range Test (DMRT) and Least Significant Different (LSD) at $\mathrm{p}=0.05$.

\section{RESULTS AND DISCUSSION}

\section{A. Initial Soil Fertility Status}

Table I shows the properties of the soil prior to experimentation in 2007. The soil is slightly acidic, sandy loam in texture with high bulk density. The soil had low Organic Matter (OM), total N, available P and exchangeable $\mathrm{K}$. The exchangeable $\mathrm{Ca}$ was deficient, while the exchangeable $\mathrm{Mg}$ was adequate. Chemical analysis of poultry manure utilized in 2007, 2008 and 2009 (Table II) indicates that it contains nutrient elements ( $\mathrm{N}, \mathrm{P}, \mathrm{K}, \mathrm{Ca}$ and $\mathrm{Mg}$ ) required for the growth of a tuber crop such as cocoyam. The Organic Carbon (OC) was the highest. It is expected that the nutrients will be released into the soil for the uptake of the crop [22].

TABLE I. SOIL PROPERTIES (0-15CM DEPTH) OF THE SITE BEFORE EXPERIMENTATION IN 2007

\begin{tabular}{ll}
\hline Property & Value \\
\hline Sand $(\%$ & 68.2 \\
Silt $(\%)$ & 16.0 \\
Clay $(\%)$ & 15.8 \\
Textural class & Sandy loam \\
$\mathrm{pH}($ water) & 5.58 \\
Bulk density $\left.\mathrm{Mg} / \mathrm{m}^{3}\right)$ & 1.55 \\
Total porosity $(\%)$ & 41.4 \\
Organic matter $(\%)$ & 2.97 \\
Total N $(\%)$ & 0.18 \\
Available P $(\mathrm{mg} / \mathrm{kg})$ & 4.5 \\
Exchangeable K $(\mathrm{cmol} / \mathrm{kg})$ & 0.15 \\
Exchangeable Ca $(\mathrm{cmol} / \mathrm{kg})$ & 1.78 \\
Exchangeable $\mathrm{Mg}(\mathrm{cmol} / \mathrm{kg})$ & 0.81 \\
\hline
\end{tabular}

TABLE II. NUTRIENT COMPOSITION OF THE POULTRY MANURE USED

\begin{tabular}{llll}
\hline Property & 2007 & 2008 & 2009 \\
\hline Organic carbon (\%) & 14.8 & 14.6 & 14.0 \\
Total N (\%) & 2.20 & 2.21 & 2.19 \\
C:N & 6.7 & 6.6 & 6.4 \\
Phosphorus (\%) & 0.83 & 0.86 & 0.82 \\
Potassium (\%) & 2.23 & 2.36 & 2.30 \\
Calcium (\%) & 1.42 & 1.40 & 1.39 \\
Magnesium (\%) & 0.58 & 0.60 & 0.57 \\
\hline
\end{tabular}

B. Effect of Tillage and Poultry Manure on Yield and Growth Parameters of Cocoyam

Table III contains data on the effect of tillage and poultry manure on yield and growth parameters of cocoyam at the end of the third year (2009). Among the tillage treatments, MC and minimally tilled MR and MM soils had higher values of corm and cormel yields, plant height and leaf area, respectively compared with mechanically tilled soils. The corm yield for MC, MR, $\mathrm{MM}, \mathrm{P}+\mathrm{H}$ and $\mathrm{P}+2 \mathrm{H}$ were $5.6,4.7,4.6,4.1$ and $3.6 \mathrm{t} / \mathrm{ha}$ respectively, values for cormel yield were 7.1, 6.0, 5.9, 4.9 and $4.7 \mathrm{t} / \mathrm{ha}$ respectively. The values for plant height were $0.49,0.40,0.41,0.35$ and $0.30 \mathrm{~m}$ respectively and the values for leaf area were $0.98,0.87,0.87,0.76$ and $0.69 \mathrm{~m}^{2}$ per plant respectively. Therefore relative to intensive repetitive mechanized tillage $(\mathrm{P}+2 \mathrm{H}), \mathrm{MC}$ increased corm and cormel yields by 56 and $51 \%$ respectively. The lower performance of cocoyam in mechanically tilled soils especially in soil with highest number of passes of implement $(\mathrm{P}+2 \mathrm{H})$ was due to lower nutrient content. The lower nutrient content in the intensively tilled plots $(\mathrm{P}+2 \mathrm{H})$ could be adduced to a number of processes such as leaching, increased biological activity and oxidation. Ref. [15] reported rapid mineralization of soil organic matter, $\mathrm{N}, \mathrm{P}, \mathrm{K}, \mathrm{Ca}$ and $\mathrm{Mg}$ for Alfisol in Nigeria due to intensive tillage. This indicates that tillage degrades soil properties with time and the degradation depends on the frequency or intensity of tillage imposed on soil [11], [23]. The growth and yield of tuber crops such as yam and cocoyam is limited by soil nutrients [11], [17], [24]. Ref. [11] observed that availability of soil nutrients dictated performance of cocoyam and that soil quality was degraded by Conventional Tillage (CT) which gave the lowest nutrient content and moisture content compared with zero tillage with mulch (ZTM), zero tillage without mulch (ZTOM), Manual Mounding (MM) and Manual Ridging (MR).

TABLE III. EFFECT OF TILLAGE AND POULTRY MANURE ON YIELD AND GROWTH PARAMETERS OF COCOYAM IN 2009 (THIRD YEAR)

\begin{tabular}{|c|c|c|c|c|c|}
\hline $\begin{array}{l}\text { Tillage } \\
\text { method }\end{array}$ & $\begin{array}{l}\text { PM } \\
\text { (t/ha) }\end{array}$ & $\begin{array}{l}\text { Corm } \\
\text { yield } \\
\text { (t/ha) }\end{array}$ & $\begin{array}{l}\text { Cormel } \\
\text { yield } \\
\text { (t/ha) }\end{array}$ & $\begin{array}{l}\text { Plant } \\
\text { height } \\
(\mathrm{m})\end{array}$ & $\begin{array}{l}\text { Leaf } \\
\text { area } \\
\left(\mathrm{m}^{2}\right)\end{array}$ \\
\hline \multirow[t]{5}{*}{$\mathrm{MC}$} & 0 & 5.6de & $7.1 \mathrm{e}$ & $0.49 \mathrm{fg}$ & $0.98 \mathrm{~d}$ \\
\hline & 2.5 & $6.4 c$ & $7.4 \mathrm{c}$ & $0.56 \mathrm{de}$ & $1.10 \mathrm{c}$ \\
\hline & 5.0 & $7.2 b$ & $8.2 b$ & $0.64 b$ & $1.21 \mathrm{~b}$ \\
\hline & 7.5 & $8.0 \mathrm{a}$ & $9.0 \mathrm{a}$ & $0.78 \mathrm{a}$ & $1.35 \mathrm{a}$ \\
\hline & 10.0 & $6.4 \mathrm{c}$ & $7.5 \mathrm{c}$ & $0.55 \mathrm{e}$ & $1.12 \mathrm{c}$ \\
\hline \multirow[t]{5}{*}{ MR } & 0 & $4.7 f$ & 6.0ghi & $0.40 \mathrm{ij}$ & $0.87 \mathrm{e}$ \\
\hline & 2.5 & $5.4 \mathrm{e}$ & $6.3 \mathrm{fg}$ & $0.44 \mathrm{hi}$ & $0.96 \mathrm{~d}$ \\
\hline & 5.0 & $5.9 \mathrm{~d}$ & $7.0 \mathrm{e}$ & $0.49 \mathrm{fg}$ & $1.11 \mathrm{c}$ \\
\hline & 7.5 & $6.6 \mathrm{c}$ & $7.9 \mathrm{~b}$ & $0.60 \mathrm{c}$ & $1.22 \mathrm{~b}$ \\
\hline & 10.0 & $4.9 \mathrm{f}$ & $6.5 f$ & $0.45 \mathrm{gh}$ & $0.95 \mathrm{~d}$ \\
\hline \multirow[t]{5}{*}{ MM } & 0 & $4.6 \mathrm{fg}$ & 5.9hij & $0.41 \mathrm{ij}$ & $0.87 \mathrm{e}$ \\
\hline & 2.5 & $5.4 \mathrm{e}^{\circ}$ & $6.2 \mathrm{fgh}$ & $0.46 \mathrm{gh}$ & $0.97 \mathrm{~d}$ \\
\hline & 5.0 & $5.9 \mathrm{~d}$ & $6.9 \mathrm{e}^{-}$ & $0.51 \mathrm{f}$ & $1.14 \mathrm{c}$ \\
\hline & 7.5 & $6.6 \mathrm{c}$ & $7.9 \mathrm{~b}$ & $0.59 \mathrm{~cd}$ & $1.26 \mathrm{~b}$ \\
\hline & 10.0 & $4.9 f$ & $6.4 f$ & $0.45 \mathrm{gh}$ & $0.98 \mathrm{~d}$ \\
\hline \multirow[t]{5}{*}{$\mathrm{P}+\mathrm{H}$} & 0 & 4.1hi & $4.9 \mathrm{kl}$ & $0.35 \mathrm{kl}$ & $0.76 f$ \\
\hline & 2.5 & $4.8 \mathrm{f}$ & $5.2 \mathrm{k}$ & $0.40 \mathrm{ij}$ & $0.84 \mathrm{e}$ \\
\hline & 5.0 & $5.3 e$ & $5.8 \mathrm{ij}$ & $0.45 \mathrm{gh}$ & $0.96 \mathrm{~d}$ \\
\hline & 7.5 & $5.8 \mathrm{~d}$ & $6.5 \mathrm{f}$ & $0.51 \mathrm{f}$ & $1.10 \mathrm{c}$ \\
\hline & 10.0 & $4.7 f$ & $5.2 \mathrm{k}$ & $0.40 \mathrm{ij}$ & $0.84 \mathrm{e}$ \\
\hline \multirow[t]{6}{*}{$\mathrm{P}+2 \mathrm{H}$} & 0 & $3.6 \mathrm{j}$ & 4.71 & $0.30 \mathrm{~m}$ & $0.69 \mathrm{~g}$ \\
\hline & 2.5 & $3.9 \mathrm{ij}$ & $5.0 \mathrm{kl}$ & $0.34 \mathrm{kl}$ & $0.76 \mathrm{f}$ \\
\hline & 5.0 & $4.3 \mathrm{gh}$ & $5.6 \mathrm{j}$ & $0.31 \mathrm{ml}$ & $0.86 \mathrm{e}$ \\
\hline & 7.5 & $4.8 \mathrm{f}$ & $6.2 \mathrm{fgh}$ & $0.46 \mathrm{gh}$ & $0.98 \mathrm{~d}$ \\
\hline & 10.0 & $3.8 \mathrm{ij}$ & $5.1 \mathrm{k}$ & $0.36 \mathrm{jk}$ & $0.77 \mathrm{f}$ \\
\hline & T X PM & $*$ & $*$ & $*$ & $*$ \\
\hline
\end{tabular}

Values followed by similar letters under the same column are not significantly different at $\mathrm{p}=0.05$ according to Duncan's multiple range test $(\mathrm{DMRT}) . *=$ Significant at $5 \%$ level of probability. $\mathrm{T}=$ Tillage method; $\mathrm{PM}=$ Poultry manure $; \mathrm{MC}=$ Manual clearing; $\mathrm{MR}=$ Manual ridging; $\mathrm{MM}=$ Manual mounding; $\mathrm{P}+\mathrm{H}=$ Ploughing plus harrowing; $\mathrm{P}+2 \mathrm{H}=$ Ploughing plus harrowing twice.

Irrespective of tillage method, corm and cormel yields, plant height and leaf area of cocoyam increased with application of PM up to $7.5 \mathrm{t} / \mathrm{ha}$. The increases dropped at 10.0t/ha (Table III). The overall mean corm yield were $4.5,5.2,5.7,6.4$ and 4.9t/ha for $0,2.5,5.0,7.5$ and 
10.0t/ha PM respectively, while mean cormel yield were $5.7,6.0,6.7,7.5$ and $6.1 \mathrm{t} /$ ha respectively. The mean values of plant height were $0.39,0.44,0.48,0.59$ and $0.44 \mathrm{~m}$ for $0,2.5,5.0,7.5$ and $10.0 \mathrm{t} /$ ha $\mathrm{PM}$ respectively. The mean values for leaf area per plant were $0.83,0.93$, 1.06, 1.18 and $0.93 \mathrm{~m}^{2}$ per plant respectively. The increase in performance of cocoyam is consistent with increase in soil and leaf nutrients associated with PM application. The finding that the $7.5 \mathrm{t} / \mathrm{ha} \mathrm{PM}$ most increased leaf $\mathrm{K}, \mathrm{Ca}$ and $\mathrm{Mg}$, yield and growth parameters of cocoyam suggests that uptake of these nutrients most dictate performance of cocoyam since increase in soil $\mathrm{K}, \mathrm{Ca}$ and $\mathrm{Mg}$ also terminated at $7.5 \mathrm{t} / \mathrm{ha}$ PM. Potassium is particularly important for carbohydrate synthesis in tuber crops [24].

The interactive effect of tillage $(\mathrm{T})$ and poultry manure (PM) for yield and growth parameters of cocoyam were significant (Table III). Out of the 25 tillage and tillage cum manure treatments, the $\mathrm{MC}+7.5 \mathrm{t} / \mathrm{ha} \mathrm{PM}$ gave the highest corm and cormel yields, plant height and leaf area of cocoyam, while the $7.5 \mathrm{t} /$ ha PM gave the highest values of yield and growth parameters. The $7.5 \mathrm{t} /$ ha $\mathrm{PM}$ also gave the highest soil and leaf $\mathrm{K}, \mathrm{Ca}$ and $\mathrm{Mg}$. It is affirmed that $\mathrm{N}$ supply and availability of the cations dictated the cocoyam performance, but at a certain soil organic $\mathrm{N}$ threshold or rather at rates exceeding $7.5 \mathrm{t} / \mathrm{ha}$ PM ammonium concentration causes toxic effects.

\section{Effect of Tillage on Soil Chemical Properties}

Table IV contains data on the effect of tillage on soil chemical properties at the end of the third year (2009). In 2009 (third year), soil OM and nutrients contents reduced with increase in tillage intensity. The MC most conserved soil OM, N, P, K, Ca and Mg and the manual tillage (MR,
MM) had higher values of soil OM and nutrients compared with mechanized tillage methods $(\mathrm{P}+\mathrm{H}$ and $\mathrm{P}+2 \mathrm{H})$. The most intensive tillage given by three passes of implement $(\mathrm{P}+2 \mathrm{H})$ gave least values of nutrients. Hence soil $\mathrm{OM}$ and nutrients reduced in the order (MC > $\mathrm{MR}=\mathrm{MM}>\mathrm{P}+\mathrm{H}>\mathrm{P}+2 \mathrm{H})$. Also the mechanized tillage methods gave least soil $\mathrm{pH}$ which is consistent with the least values recorded for the cations $\mathrm{K}, \mathrm{Ca}$ and $\mathrm{Mg}$. Reduction in soil $\mathrm{OM}$ and nutrients due to tillage is attributable to loss and oxidation of organic matter [25[, ]26], which is natural source of nutrients. Also, the initially porous nature of tilled soils especially in the first two years [27] might have enhanced leaching of nutrients to subsoil. The MC, form of zero tillage, had highest soil $\mathrm{OM}$ and nutrients content. Zero tillage is known to conserve soil fertility in the long-run [27]. It gave highest concentration of nutrients under cocoyam in the third year of cropping compared with manual and mechanized tillage methods.

\section{Effect of Poultry Manure on Soil Chemical Properties}

Table V shows data on the effect of poultry manure on soil chemical properties at the end of the third year (2009). Irrespective of tillage method, soil $\mathrm{pH}$, OM, total $\mathrm{N}$, available $\mathrm{P}$, exchangeable $\mathrm{K}, \mathrm{Ca}$ and $\mathrm{Mg}$ increased with level of Poultry Manure (PM) from 0 to $10.0 \mathrm{t} / \mathrm{ha}$. In case of $\mathrm{K}, \mathrm{Ca}$ and $\mathrm{Mg}$, however, the 7.5t/ha PM gave highest values in all instances. General increase in soil nutrients content with addition of PM is consistent with the fact that PM is a natural and effective source of nutrients [28]-[31] and its presence also increases cation exchange capacity of soil. It also has liming effect [31].

TABLE IV. EFFeCt of Tillage on Chemical Properties (0-15CM) IN 2009 (ThIRD YeAR)

\begin{tabular}{lllllllll}
\hline Tillage method & $\mathrm{pH}\left(\mathrm{H}_{2} \mathrm{O}\right)$ & $\begin{array}{l}\mathrm{OM} \\
(\%)\end{array}$ & $\begin{array}{l}\mathrm{N} \\
(\%)\end{array}$ & $\begin{array}{l}\mathrm{P} \\
(\mathrm{mg} / \mathrm{kg})\end{array}$ & & $\mathrm{K}$ & $\mathrm{Ca}$ & $\mathrm{Mg}$ \\
\cline { 7 - 9 } & & & & & & & & \\
$\mathrm{MC}$ & $5.5 \mathrm{a}$ & $2.85 \mathrm{a}$ & $0.14 \mathrm{a}$ & $3.9 \mathrm{a}$ & $0.13 \mathrm{a}$ & $1.61 \mathrm{a}$ & $0.72 \mathrm{a}$ \\
$\mathrm{MR}$ & $5.4 \mathrm{a}$ & $2.51 \mathrm{~b}$ & $0.12 \mathrm{~b}$ & $3.2 \mathrm{~b}$ & $0.10 \mathrm{~b}$ & $1.31 \mathrm{~b}$ & $0.69 \mathrm{ab}$ \\
$\mathrm{MM}$ & $5.4 \mathrm{a}$ & $2.49 \mathrm{~b}$ & $0.12 \mathrm{~b}$ & $3.1 \mathrm{~b}$ & $0.10 \mathrm{~b}$ & $1.30 \mathrm{~b}$ & $0.69 \mathrm{ab}$ \\
$\mathrm{P}+\mathrm{H}$ & $5.1 \mathrm{ab}$ & $2.20 \mathrm{c}$ & $0.10 \mathrm{c}$ & $2.7 \mathrm{c}$ & $0.08 \mathrm{c}$ & $1.12 \mathrm{c}$ & $0.66 \mathrm{~b}$ \\
$\mathrm{P}+2 \mathrm{H}$ & $5.0 \mathrm{ab}$ & $1.98 \mathrm{~d}$ & $0.09 \mathrm{~d}$ & $2.3 \mathrm{~d}$ & $0.06 \mathrm{~d}$ & $1.01 \mathrm{~d}$ & $0.65 \mathrm{~b}$
\end{tabular}

Values followed by similar letters under the same column are not significantly different at $\mathrm{p}=0.05$ according to Duncan's multiple range test $(\mathrm{DMRT}) ; \mathrm{MC}=$ Manual clearing; $\mathrm{MR}=\mathrm{Manual}$ ridging; $\mathrm{MM}=\mathrm{Manual}$ mounding; $\mathrm{P}+\mathrm{H}=\mathrm{Ploughing}$ plus harrowing; $\mathrm{P}+2 \mathrm{H}=\mathrm{Ploughing}$ plus harrowing twice.

TABLE V. EFFect of Poultry MANure on SOIL ChEMiCAl Properties (0-15CM) IN 2009 (ThIRD YeAR)

\begin{tabular}{cccccccc}
\hline $\begin{array}{c}\mathrm{PM} \\
\mathrm{t} / \mathrm{ha}\end{array}$ & $\begin{array}{c}\mathrm{pH} \\
\text { (water) }\end{array}$ & $\begin{array}{c}\mathrm{OM} \\
(\%)\end{array}$ & $\begin{array}{c}\mathrm{N} \\
(\%)\end{array}$ & $\begin{array}{c}\mathrm{P} \\
(\mathrm{mg} / \mathrm{kg})\end{array}$ & $\mathrm{K}$ & $\mathrm{Ca}$ & $\mathrm{Mg}$ \\
\cline { 6 - 8 } & & & & & & $(\mathrm{cmol} / \mathrm{kg})$ & \\
\hline 0 & $5.3 \mathrm{bc}$ & $2.41 \mathrm{e}$ & $0.11 \mathrm{e}$ & $3.0 \mathrm{e}$ & $0.09 \mathrm{e}$ & $1.30 \mathrm{~d}$ & $0.68 \mathrm{~d}$ \\
2.5 & $5.4 \mathrm{bc}$ & $2.82 \mathrm{~d}$ & $0.13 \mathrm{~d}$ & $3.5 \mathrm{~d}$ & $0.10 \mathrm{~d}$ & $1.46 \mathrm{c}$ & $0.77 \mathrm{c}$ \\
5.0 & $5.6 \mathrm{ab}$ & $3.14 \mathrm{c}$ & $0.15 \mathrm{c}$ & $4.0 \mathrm{c}$ & $0.12 \mathrm{c}$ & $1.72 \mathrm{~b}$ & $0.99 \mathrm{~b}$ \\
7.5 & $5.8 \mathrm{a}$ & $3.51 \mathrm{~b}$ & $0.17 \mathrm{~b}$ & $4.7 \mathrm{~b}$ & $0.15 \mathrm{a}$ & $1.96 \mathrm{a}$ & $1.19 \mathrm{a}$ \\
10.0 & $5.9 \mathrm{a}$ & $3.96 \mathrm{a}$ & $0.20 \mathrm{a}$ & $5.2 \mathrm{a}$ & $0.14 \mathrm{ab}$ & $1.94 \mathrm{a}$ & $1.17 \mathrm{a}$ \\
\hline
\end{tabular}

Values followed by similar letters under the same column are not significantly different at $\mathrm{p}=0.05$ according to Duncan's Multiple Range Test (DMRT); PM = Poultry manure. 


\section{E. Effect of Tillage on Leaf Nutrients Composition of Cocoyam}

Table VI contains data on the effect of tillage on leaf nutrients composition of cocoyam at the end of the third year (2009). Leaf nutrients content reduced with tillage intensity; Hence leaf $\mathrm{N}, \mathrm{P}, \mathrm{K}, \mathrm{Ca}$ and $\mathrm{Mg}$ reduced in the order $\mathrm{MC}>\mathrm{MR}=\mathrm{MM}>\mathrm{P}+\mathrm{H}>\mathrm{P}+2 \mathrm{H}$. Expectedly the manual methods (MM, MR) had similar values. The most intense and repetitive tillage method $(\mathrm{P}+2 \mathrm{H})$ had least values of leaf nutrients. This finding is consistent with the finding that tillage reduced soil nutrients content over three years. The reduction led to decrease in nutrients uptake by cocoyam. In their study with sorghum, Agbede and Ojeniyi [27] also observed that zero tillage gave highest leaf $\mathrm{N}, \mathrm{P}, \mathrm{K}, \mathrm{Ca}$ and $\mathrm{Mg}$ concentrations in sorghum compared with $\mathrm{MC}, \mathrm{PL}$ (ploughing), $\mathrm{P}+\mathrm{H}$ and $\mathrm{P}+2 \mathrm{H}$. They also noted that nutrients concentration in sorghum decreased with frequency and intensity of soil manipulation. This was attributed to better soil fertility and water content adduced to zero tillage. The lower leaf nutrients observed by the authors for sorghum plants on mechanically tilled soils was adduced to soil degradation and lower moisture content which adversely affected nutrient uptake. Study by Adekiya et al. [4] showed that in the first two years MC gave highest values of soil chemical properties under cocoyam compared with manual and mechanized tillage.

TABLE VI. EFFECT OF TILLAGE ON LEAF NUTRIENTS COMPOSITION OF COCOYAM IN 2009 (THIRD YEAR)

\begin{tabular}{llllll}
\hline $\begin{array}{l}\text { Tillage } \\
\text { method }\end{array}$ & $\begin{array}{l}\mathrm{N} \\
(\%)\end{array}$ & $\begin{array}{l}\mathrm{P} \\
(\%)\end{array}$ & $\begin{array}{l}\mathrm{K} \\
(\%)\end{array}$ & $\begin{array}{l}\mathrm{Ca} \\
(\%)\end{array}$ & $\begin{array}{l}\mathrm{Mg} \\
(\%)\end{array}$ \\
\hline $\mathrm{MC}$ & $2.16 \mathrm{a}$ & $0.37 \mathrm{a}$ & $0.32 \mathrm{a}$ & $0.52 \mathrm{a}$ & $0.27 \mathrm{a}$ \\
$\mathrm{MR}$ & $1.90 \mathrm{bc}$ & $0.30 \mathrm{~b}$ & $0.28 \mathrm{~b}$ & $0.42 \mathrm{~b}$ & $0.22 \mathrm{~b}$ \\
$\mathrm{MM}$ & $1.96 \mathrm{~b}$ & $0.31 \mathrm{~b}$ & $0.28 \mathrm{~b}$ & $0.41 \mathrm{~b}$ & $0.21 \mathrm{~b}$ \\
$\mathrm{P}+\mathrm{H}$ & $1.77 \mathrm{c}$ & $0.26 \mathrm{c}$ & $0.22 \mathrm{c}$ & $0.36 \mathrm{c}$ & $0.18 \mathrm{c}$ \\
$\mathrm{P}+2 \mathrm{H}$ & $1.60 \mathrm{~d}$ & $0.22 \mathrm{~d}$ & $0.19 \mathrm{~d}$ & $0.32 \mathrm{~d}$ & $0.15 \mathrm{~d}$ \\
\hline
\end{tabular}

Values followed by similar letters under the same column are not significantly different at $\mathrm{p}=0.05$ according to Duncan's multiple range test $(\mathrm{DMRT}) . \mathrm{MC}=\mathrm{Manual}$ clearing; $\mathrm{MR}=$ Manual ridging; $\mathrm{MM}=$ Manual mounding; $\mathrm{P}+\mathrm{H}=$ Ploughing plus harrowing; $\mathrm{P}+2 \mathrm{H}=$ Ploughing plus harrowing twice

\section{F. Effect of Poultry Manure on Leaf Nutrients Composition of Cocoyam}

Table VII shows data on the effect of poultry manure on leaf nutrients composition of cocoyam at the end of the third year (2009). Irrespective of tillage method, leaf $\mathrm{N}$ and $\mathrm{P}$ increased with the level of $\mathrm{PM}$ from 0 to 10.0t/ha. In case of $\mathrm{K}, \mathrm{Ca}$ and $\mathrm{Mg}$ the increase persisted up to $7.5 \mathrm{t} / \mathrm{ha} \mathrm{PM}$ and it dropped at $10.0 \mathrm{t} / \mathrm{ha} \mathrm{PM}$. It is affirmed that PM enhanced uptake of $\mathrm{N}, \mathrm{P}, \mathrm{K}, \mathrm{Ca}$ and $\mathrm{Mg}$ by cocoyam. Similar observation was made with respect to sorghum [27] that PM at 7.5t/ha significantly increased leaf $\mathrm{N}, \mathrm{P}, \mathrm{K}, \mathrm{Ca}$ and $\mathrm{Mg}$. The decreasing nutrients content in leaves at $10.0 \mathrm{t} /$ ha $\mathrm{PM}$ is due to some nutrient imbalances between cations which have not been measured (e.g. $\mathrm{NH}_{4}^{+}, \mathrm{Na}^{+}$) on the one hand and $\mathrm{K}, \mathrm{Ca}$ and $\mathrm{Mg}$ on the other hand or it is related to ammonium toxicity and hence lower uptake rates. It could be seen that soil $\mathrm{pH}$ increased with $\mathrm{PM}$ up to $10.0 \mathrm{t} / \mathrm{ha}$. In the study with cassava, Odedina et al. [31] also found that PM increased leaf $\mathrm{N}, \mathrm{K}$ and $\mathrm{Mg}$ in addition to increasing soil $\mathrm{K}, \mathrm{Ca}$ and $\mathrm{Mg}$.

TABLE VII. EFFECT OF POULTRY MANURE ON LEAF NUTRIENTS COMPOSITION OF COCOYAM IN 2009 (THIRD YEAR)

\begin{tabular}{llllll}
\hline $\mathrm{PM}$ & $\mathrm{N}$ & $\mathrm{P}$ & $\mathrm{K}$ & $\mathrm{Ca}$ & $\mathrm{Mg}$ \\
$\mathrm{t} / \mathrm{ha}$ & $(\%)$ & $(\%)$ & $(\%)$ & $(\%)$ & $(\%)$ \\
\hline 0 & $1.88 \mathrm{e}$ & $0.29 \mathrm{e}$ & $0.26 \mathrm{~d}$ & $0.43 \mathrm{~d}$ & $0.21 \mathrm{e}$ \\
2.5 & $2.09 \mathrm{~d}$ & $0.33 \mathrm{~d}$ & $0.30 \mathrm{c}$ & $0.48 \mathrm{c}$ & $0.25 \mathrm{c}$ \\
5.0 & $2.39 \mathrm{c}$ & $0.38 \mathrm{c}$ & $0.34 \mathrm{~b}$ & $0.54 \mathrm{~b}$ & $0.30 \mathrm{~b}$ \\
7.5 & $2.68 \mathrm{~b}$ & $0.44 \mathrm{~b}$ & $0.40 \mathrm{a}$ & $0.63 \mathrm{a}$ & $0.34 \mathrm{a}$ \\
10.0 & $2.97 \mathrm{a}$ & $0.50 \mathrm{a}$ & $0.31 \mathrm{c}$ & $051 \mathrm{bc}$ & $027 \mathrm{~cd}$ \\
\hline
\end{tabular}

Values followed by similar letters under the same column are not significantly different at $\mathrm{p}=0.05$ according to Duncan's Multiple Range Test (DMRT); PM = Poultry manure

\section{CONCLUSIONS}

For sustainable and enhanced productivity of cocoyam, soil fertility and nutrient availability, combination of manual clearing and poultry manure at $7.5 \mathrm{t} / \mathrm{ha}$ is recommended in the study area. Manual clearing most preserved soil fertility and sustained higher yield and growth of cocoyam while manure at 7.5 t/ha most improved yield and growth of cocoyam and nutrients concentration.

\section{REFERENCES}

[1] D. F. Uwah, A. U. Udoh, and G. A. Iwo, "Effect of organic and mineral fertilizers on growth and yield of cocoyam (Colocasia esculenta (L.) Schott)," International Journal of Agricultural Sciences, vol. 3, no, 1, pp. 33-38, March 2011.

[2] I. C. Onwueme and T. D. Sinha, Field Crop Production in Tropical Africa, The Netherlands: CTA, Ede, 1991, pp. 1-480.

[3] Handbook of Horticulture, Indian Council of Agricultural Research, New Delhi, Som, D, 2007, pp. 507-508.

[4] A. O. Adekiya, S. O. Ojeniyi, and T. M. Agbede, "Soil physical and chemical properties and cocoyam yield under different tillage systems in a tropical Alfisol," Experimental Agriculture, vol. 47, no. 3, pp. 477-488, July 2011.

[5] M. R. Villanueva, "Technology for yam and taro production in Southeast Asia," Radix, vol. 8, pp. 1-6, 1986.

[6] S. P. Ghosh, T. Ramanujam, J. S. Jos, S. N. Moorthy, and R. G. Nair, Tuber Crops, New Delhi, India: Oxford and IBH Publishing Company, 1988.

[7] J. R. Pardales and F. G. Villamayor, "Cultural management studies on upland taro. Effects of cultivation systems on growth and yield of taro and incidence of associated weeds," Annals of Tropical Research, vol. 5, pp. 13-22, 1983.

[8] B. A. C. Enyi, "Effects of age on establishment and yield of cocoyam setts (Xanthosoma sagittifolium Schott)," Experimental Agriculture, vol. 3, pp. 121-127, 1967.

[9] I. C. Onwueme, The Tropical Tuber Crops: Yams, Cassava, Sweet Potato and Cocoyams, New York: John Wiley, 1978.

[10] D. L. Plucknett, H. C. Ezumah, and R. S. D. L. Pena, "Mechanization of taro (Colocasia esculenta) culture in Hawaii," in Proc. 3rd Symposium of International Society of Root Crops, Ibadan, Nigeria, Dec. 2-9, 1973, pp. 286-292.

[11] T. M. Agbede, "Nutrient availability and cocoyam yield under different tillage practices," Soil Tillage Research, vol. 99, no. 1, pp. 49-56, April 2008

[12] P. E. Ogbonna and N. J. Nweze, "Evaluation of growth and yield responses of cocoyam (Colocasia esculenta) cultivars to rates of NPK 15:15:15 fertilizer," African Journal of Agricultural Research, vol. 7, no. 49, pp. 6553-6561, December 2012.

[13] M. N. Obasi, E. N. A. Mbanaso, and A. O. Ano, "Effects of animal manure on performance and yield of cocoyam (Xanthosoma sagittifolium) in an Ultisol of southwestern 
Nigeria," in Proc. 39th Annual Conference of Agricultural Society of Nigeria, Edo State, Nigeria, Oct. 9-13, 2005, pp. 140-142.

[14] E. Z. Nyakatawa, K. C. Reddy, and K. R. Sistani, "Tillage, cover cropping and poultry manure litter effects on selected soil chemical properties," Soil Tillage Research, vol. 58, no. 1-2, pp. 69-79, February 2001.

[15] FAO, "World reference base of soil resources. World soil resources report 84," Foods and Agriculture Organization of the United Nations, Rome, 1998.

[16] A. O. Adekiya, S. O. Ojeniyi, and T. M. Agbede, "Poultry manure effects on soil properties, leaf nutrient status, growth and yield of cocoyam in a tropical Alfisol," Nigerian Journal of Soil Science, vol. 22, no. 2, pp. 30-39, 2012.

[17] I. L. Hamma, B. A. Mahmoud, A. Wakili, and M. A. Hayatuddeen, "Performance of cocoyam (Colocasia esculentus L.) as influenced by organic and inorganic manure in Samaru, Zaria, Nigeria," International Journal of Agronomy and Agricultural Research, vol. 5, no. 5, pp. 97-103, November 2014

[18] W. Horwitz and G. W. Latimer, Official Methods of Analysis of Association of Official Analytical Chemists, 18th ed., AOAC International, 2006.

[19] N. R. Hulugalle, R. Lal, and O. A. Opara-Nadi, "Effect of tillage system and mulch on soil properties and growth of yam (Dioscorea rotundata) and cocoyam (Xanthosoma sagittifolium) on an Ultisol," Journal of Root Crops, vol. 11, no. 1-2, pp. 9-22, 1985.

[20] B. A. Ndon, N. H. Ndulaka, and N. U. Ndaeyo, "Stabilization of yield parameters and some nutrient components in cocoyam cultivars with time in Uyo, southeastern Nigeria," Global Journal of Agricultural Sciences, vol. 2, no. 2, pp. 74-78, 2003

[21] A. Agueguia, "Non-Destructive estimation of leaf area in cocoyam (Xanthosoma sagittifolium (L.) Schott)," Journal of Agronomy and Crop Science, vol. 171, no. 2, pp. 138-141, September 1993.

[22] E. A. Makinde, L. S. Ayeni, and S. O. Ojeniyi, "Effects of organic, organomineral and NPK fertilizer treatments on the nutrient uptake of Amaranthus cruentus (L.) on two soil types in Lagos, Nigeria," Journal of Central European Agriculture, vol. 12, no. 1, pp. 114-123, 2011.

[23] T. M. Agbede and J. O. Ogundele, "Effect of tillage systems and Tithonia diversifolia mulch on soil physical and chemical properties, growth and cocoyam yield in a tropical Alfisol," British Journal of Applied Science and Technology, vol. 7, no. 5, pp. 483-495, March 2015.

[24] T. M. Agbede, A. O. Adekiya, and J. S. Ogeh, "Effects of organic fertilizers on yam productivity and some soil properties of a nutrient-depleted tropical Alfisol," Archives of Agronomy and Soil Science, vol. 59, no. 4-6, pp. 803-822, 2013.

[25] S. O. Ojeniyi and F. O. Adekayode, "Soil conditions and cowpea and maize yield produced by tillage methods in the rainforest zone of Nigeria," Soil Tillage Research, vol. 51, no. 1-2, pp. 161-164, July 1999.

[26] S. O. Ojeniyi and F. O. Adekayode, "Soil fertility status and maize yield under different tillage systems," Samaru Journal of Agricultural Research, vol. 18, pp. 83-89, 2002.

[27] T. M. Agbede and S. O. Ojeniyi, "Tillage and poultry manure effects on soil physical properties, nutrients status, growth, dry matter and grain yield of sorghum," Journal of Agricultural Science and Technology, vol. 4, no. 3, pp. 45-59, June 2010.

[28] A. P. Maerere, G. G. Kimbi, and D. L. M. Nonga, "Comparative effectiveness of animal manures on soil chemical properties, yield and root growth of amaranthus (Amaranthus cruentus L.)," African Journal of Science and Technology, vol. 1, no. 4, pp. 1421, January 2001.

[29] T. M. Agbede and S. O. Ojeniyi, "Tillage and poultry manure effects on soil fertility and sorghum yield in southwestern Nigeria," Soil Tillage Research, vol. 104, no. 1, pp. 74-81, June 2009.

[30] L. S. Ayeni, T. O. Omole, E. O. Adeleye, and S. O. Ojeniyi, "Integrated application of poultry manure and NPK fertilizer on performance of tomato in derived savannah transition zone of Southwest Nigeria," Science and Nature, vol. 8, no. 2, pp. 50-54, 2010.

[31] J. N. Odedina, S. O. Ojeniyi, and S. A. Odedina, "Comparative effect of animal manures on soil nutrients status and performance of cassava," Nigerian Journal of Soil Science, vol. 21, no. 1, pp. 58-63, 2011.

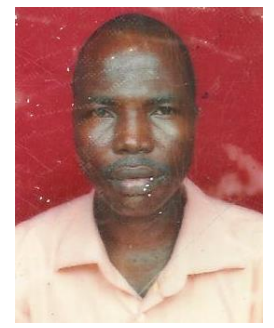

Aruna O. Adekiya was born in Owo, Ondo State, Nigeria in 1967. He obtained the Ph.D. degree in Soil Management from the Federal University of Technology, Akure, Ondo State, Nigeria in 2014. He is currently a lecturer in the Department of Crop and Soil Sciences, Landmark University, Omu-Aran Kwara State, Nigeria. His research interests include soil tillage and soil fertility management.

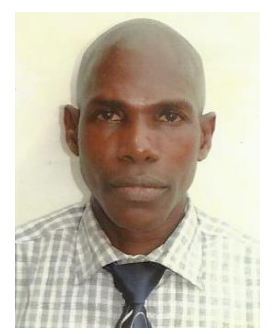

Taiwo M. Agbede was born in Owo, Ondo State, Nigeria in 1964. He obtained the Ph.D. degree in Soil Management from the Federal University of Technology, Akure, Ondo State, Nigeria in 2008. He is currently a principal lecturer and head of Department of Agricultural Technology, Rufus Giwa Polytechnic, Owo, Ondo State, Nigeria. His research interests include soil tillage, mulching, use of organic and inorganic fertilizers. 